\title{
Okul Öncesi Dönem Çocuklarının Motivasyon Düzeyleri ile Baba-Çocuk İlişkisi Arasındaki İlişkinin İncelenmesi
}

\author{
Ayşe Gözübüyük ${ }^{1^{*}}$ \\ Prof. Dr. Saide Özbey ${ }^{2}$
}

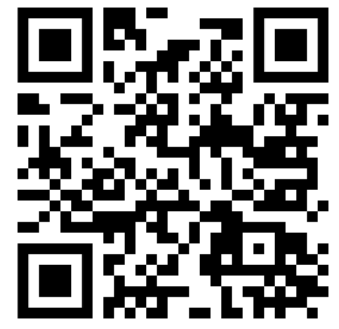

Gelis tarihi: 03.07.2020

Kabul tarihi: 23.08.2020

\section{Atıf bilgisi:}

IBAD Sosyal Bilimler Dergisi

Sayı: Özel Sayı Sayfa: 23-37

Yıl: 2020

This article was checked by Turnitin.

Similarity Index 26\%

Bu makalede araştırma ve yayın etiğine uyulmuş̧tur.

${ }^{1}$ Gazi Üniversitesi, Türkiye, aysegurlu1903@gmail.com,

ORCID ID 0000-0002-7544-3610

${ }^{2}$ Gazi Üniversitesi, Türkiye, saideozbey@gmail.com,

ORCID ID 0000-0001-8487-7579

* Sorumlu yazar
ÖZ

Araştırma okul öncesi eğitim kurumlarına devam eden 48-72 aylık çocukların motivasyon düzeyleri ile baba-çocuk ilişkisi arasındaki ilișkiyi incelemek amacıyla planlanmıştır. Bununla birlikte baba-çocuk ilişkisinin babanın yaşı, öğrenim durumu, mesleği gibi değișkenlere göre farklllık gösterip göstermediği sorusuna da cevap aranmıştır. Araştırmada ilişkisel tarama modeli kullanılmıştır. Araştırmanın evrenini, 2018-2019 eğitim öğretim yılında Diyarbakır'ın Silvan ilçesinde bulunan Milli Eğitim Bakanlığı bünyesindeki ilkokula bağlı anasınıfları ve bağımsız anaokullarına devam eden 48-72 aylık çocuklar oluşturmaktadır. Araştırmanın örneklemini evrenden tesadüfî küme örnekleme formülü kullanılarak belirlenmis 331 çocuk oluşturmaktadır. Veriler "Genel Bilgi Formu", "Okul Öncesi Çocuklar İçin Motivasyon Ölçeği”" ve "Çocuk Ebeveyn İlişki Ölçeği (Baba Formu)" kullanılarak elde edilmiştir. Araştırma sonucunda baba-çocuk ilişkisi toplam puanlarının babanın yaşı ve babanın öğrenim durumu değişkenlerine göre anlamlı farklılık göstermediği ( $>0.05)$; babanın mesleği değișkenine göre anlamlı farklılık gösterdiği $(\mathrm{p}<0.05)$; baba-çocuk ilişkisi ile çocukların motivasyon düzeyleri arasında negatif yönde, anlamlı ve orta düzeyde ilișki olduğu saptanmıștır $(p<0.05)$.

Anahtar Kelimeler: Okul öncesi, Motivasyon, Baba-çocuk ilişkisi 


\title{
Investigation of the Relationship Between Motivational Levels of Preschool Children and Father-Child Relationships
}

\author{
Ayşe Gözübüyük ${ }^{1 *}$ \\ Prof. Dr. Saide Özbey ${ }^{2}$
}

First received: 03.07 .2020

Accepted: 23.08 .2020

\section{Citation:}

IBAD Journal of Social Sciences

Issue: Special Issue Pages: 23-37

Year: 2020

This article was checked by Turnitin. Similarity Index 26\%

\footnotetext{
${ }^{1}$ Gazi University, Turkey, aysegurlu1903@gmail.com, ORCID ID 0000-0002-7544-3610
}

${ }^{2}$ Gazi University, Turkey, saideozbey@gmail.com,

ORCID ID 0000-0001-8487-7579

* Corresponding Author

\begin{abstract}
The research was planned to investigate the relationship between the motivation levels and father-child relationship of children, aged 48-72 months, attending preschool education institutions. In addition, the question of whether the father-child relationship differs according to the variables such as father's age, education level and occupation was also searched. In the research, relational screening model was used. The population of the study consists of 48-72 months old children attending kindergartens connected to primary school and independent kindergartens within the Ministry of Education in the Silvan district of Diyarbakır in the 2018-2019 academic year. The sample of the study consists of 331 children from the universe determined by using random cluster sampling formula. Data were obtained by using "General Information Form", "The Motivation Scale for Preschool Children" and "Child Parent Relationship Scale (by fathers)". As a result of the study, the total scores of the father-child relationship did not differ significantly according to the age of the father and the educational status of the father $(p>0.05)$ but it was different significantly from according to father's profession ( $p<0.05$ ); additionally it was a negative, significant, and moderate relationship between father-child relationship and motivation levels of children $(\mathrm{p}<0.05)$.
\end{abstract}

Keywords: Preschool, Motivation, Father-child relationship 


\section{GIRISS}

Çocuk aktif, sorgulayıcı, meraklı, öğrenmek ve keşfetmek için hazır olarak doğal bir motivasyon eğilimi ile dünyaya gelmektedir. Bu doğal motivasyon eğilimi çocuğun ilgi alanları üzerinde harekete geçerek bilgi ve beceri olarak ortaya çıktığ için bilişsel, sosyal ve fiziksel gelişimde önemli bir unsurdur (Topçu, 2015). Çocukta beceri ve motivasyonun bir arada bulunması, kendi performans yeteneğini olumlu algılamasını, faaliyetin yönünü, faaliyete yönelik harcanan çaba miktarını ve stresli bir durumdaki azmini güçlü bir şekilde etkilemektedir (Bandura, 1977). Bu nedenle motivasyon sürecini anlamak için bireyleri hedefleri yönünde zorlayan sebeplerin, amaç ve davranışlarını sürdürebilme olanaklarının araştırılması gerekmektedir. Motivasyon istek, arzu, ihtiyaç, dürtü ve ilgiyi içermektedir (Güney, 2012).

Motivasyon ile ilgili farklı tanımlar bulunmaktadır. Akbaba (2006) motivasyonun bireyleri davranışlara yönelten, davranışların şiddetini ve enerjisini belirleyen, davranışlara yön veren ve sürdürülmesini sağlayan içsel ve dişsal faktörler ve bunların işleyişlerini kapsadığını ifade etmektedir. Woolfolk (1999)'a göre motivasyon yalnızca insanın kendisinin yönlendirdiği, bireyi amaçlarına yönelten içsel bir güçtür. Tucker, Edmondson ve Spear (2002)'ın tanımlamalarına göre ise motivasyon, çocuğun eğitime ilişkin yatırımını ve bağlılığını şekillendiren zihinsel, duygusal ve davranışsal belirleyicileridir (Ergin ve Karataş, 2018). Bu belirleyiciler çocuğun bazen içinden bazen de dışından gelmektedir. $\mathrm{Bu}$ durum ise motivasyonun içsel ve dışsal motivasyon olarak iki kaynaktan ortaya çıktığını göstermektedir. İçsel motivasyonda davranışa yönelten sebepler çocuğun içinden gelen ilgi, merak ve haz almakla ilişkilidir. Dışsal motivasyonda ise çocuğun hedef yönünde davranış sarf etmesi için dıştan verilen teşvik, ödül gibi pekiştireçler ön plana çıkmaktadır (Demir, 2018). İçsel motivasyon, çocuğun isteğiyle hareket ederek çalışmasıdır. İçsel motivasyonun çocukta etkileri ilgi, merak, gereksinim gibi içten gelir ve çocuğun içsel gereksinimlere yönelik verdiği tepkilerdir. Dışsal motivasyon ise ödül, ceza gibi dışsal pekiştireçlerin etkisiyle meydana gelmektedir (Yücel Batmaz ve Gürer, 2016). İçsel motivasyon, dıştan bakıldığında anlaşılması ve algılanması zaman alabilirken bunun aksine dışsal motivasyon, ortaya çıkan sonuçlara bakılarak kolaylıkla fark edilebilmektedir. Dışsal motive olan çocuklar için, yakın çevrelerindeki kişilerin negatif düşüncelerinden kaçınmak esastır (Dede ve Argün, 2004).

İçsel motivasyona sahip çocukların, yaptıkları işten aldıkları doyumun daha fazla olduğu, her daim bir amaca ulaşmak için çalıştıkları ve bundan dolayı mutlu oldukları, hayatlarında onlara mutluluğu, başarıyı getiren belirli ilkelere göre davrandıkları görülmektedir. Aynı zamanda içsel motive olan çocuklar hem kendilerine hem de topluma daha kolay uyum sağlamaktadır (Özbey, 2018a). Ayrıca içsel motive olan çocukların, öğrenmeye karşı daha istekli, akademik anlamda daha başarılı, zorluklardan hemen vazgeçmeyen, daha heyecanlı, daha fazla çaba gerektiren ve daha yoğun bilgi kullanmaya imkan tanıan stratejilerden yararlanma eğiliminde oldukları bilinmektedir (Topçu, 2015).

Erken çocukluk döneminde içsel motivasyonun gelişim sürecinde kalıtımın yanı sıra çocuğun içinde bulunduğu toplum ve aile gibi çevresel etkenler oldukça önem taşımaktadır. Motivasyon için temel teşkil eden güven, özerklik ve girişimcilik duygularının gelişimi öncelikle sağlıklı aile ilişkileriyle mümkündür (Özkan, 2014). Aile çocuğun beslenmesi, barınması, korunması ve öğrenmesi yönünde firsatlar oluşturur. Ailenin çocuğa ilgili, sevgi dolu ve şefkatli olması, gereksinimlerini yerinde ve vaktinde karşılamasıyla çocukta güven duygusunun temeli oluşmaktadır (Aktürk, 2015). Aile denilince akla ilk gelen çocuğun anne ve babasıdır. Çocuğun sorumluluğunun ait olduğu aile kurumunda çocuktan ilk olarak sorumlu görülen ve önemi üzerinde durulan kişi ise genellikle annedir (Özkan, 2014). İlkel toplumlardan bu güne kadar babanın asıl sorumluluğu; ailenin barınma, beslenme gibi gereksinimlerini karşılamak olarak görülmektedir. Günümüzde babalar bu sorumluluğun bir kısmını eşleriyle paylaşmalarına rağmen babaların çoğunluğu bütün günlerini çalışarak geçirmektedir. Babaların evlerinde olarak çocuklarıyla geçirdikleri vakitler genel olarak akşam saatleriyle hafta sonlarıdır. Babaların çocuklarıyla geçirdikleri zamanın ne kadar olduğu değil nitelikli olup olmadığı önemlidir. Bu yüzden baba ile çocuğun birlikte geçirdikleri zaman sınırlı dahi olsa nitelikli ise çocuk bu etkileşimden yeteri kadar yararlanabilmektedir. Okul öncesi dönemde baba ile çocuğun etkili iletişimi ve nitelikli paylaşımları daha sağlıklı bireyler yetişmesine ve daha kaliteli toplumlar oluşmasına katkı sağlamaktadır (Ünüvar, 2008). 
Babası hayatına aktif katılan çocuklar, akran ilişkilerinde daha olumlu, daha iyi bilişsel, sosyal ve dil gelişimlerine sahip olmakla birlikte davranış ve duygu düzenlemeleri daha iyi olmaktadır (Tezel Şahin, Akıncı Coşgun ve Kılıç Aydın, 2017). Çocuğuna ilgi ve sevgi gösteren, çocuğun düzeyinde, bilişsel gelişimini ve özerkliğini destekleyici şekilde davranan babalar sayesinde çocuklar kolay iletişim kuran, araştırmacı, mutlu, liderlik özelliklerini taşıyan, bağımlı olmayan ve uyumlu bireyler olmaktadır (Poyraz, 2007). Bunun yanında babaları ile sıcak ilişki kuran çocukların akademik olarak başarılı, antisosyal davranışları ise daha az sergileyen bireyler oldukları ve yaşamları süresince akranları ile ilişkilerinin daha iyi olduğu gözlenmektedir (Atmaca Koçak, 2004).

Yapılan çalışmalar baba-çocuk arasındaki ilişkinin çocukların bilişsel gelişiminde ve okul başarısında büyük ölçüde etkili olduğunu ve babanın çocuğun kişilik gelişiminde özdeşim modeli olmasından dolayı önemini vurgulamaktadır (Yavuzer, 2012, s. 23). Amato ve Rivera (1999)'ın çalışması babanın ilgisiyle çocuklardaki davranış sorunlarının ters orantılı olduğunu göstermektedir. Easterbrooks ve Goldberg (1984) tarafından yapılan çalışma ise babaların çocuklarının bakımına dahil olmasının, çocukların bilişsel gelişimi ve problem çözme becerileri üstünde olumlu etkisi olduğunu göstermektedir (Aktaran Atmaca Koçak, 2004). Arslan ve Durmaz Kandaz (2004)'ın yaptıkları çalışmada babaların çocuklarına aktif şekilde ayırdıkları zamanın çocukların problemlere karşı baş etmelerinde etkili olduğu sonucuna ulaşılmıştır. Mwoma (2009) çalışmasında babaların çocukların eğitimine katılmalarıyla çocukların başarısı arasındaki ilişkinin pozitif yönde ve anlamlı olduğunu saptamıştır. Türkoğlu, Çeliköz ve Uslu (2013)'nun yaptığı çalışmada ise babaların, çocukları ile geçirdikleri nitelikli zamanın özellikle çocukları sosyal-duygusal açıdan geliştirdiği görüşünü savundukları saptanmıştır. Yapılan çalışmalar erken yaşlarda başlayan olumlu baba-çocuk ilişkisinin çocuğun bütün gelişim alanları üzerindeki etkisine dikkati çekmektedir. Bununla birlikte okul öncesi dönemdeki çocukların baba-çocuk ilişkisini ele alan çalışmalar var olsa da (Ünüvar, 2008; Buckley ve Schoppe-Sullivan, 2010; Uzun ve Baran, 2019) babaçocuk ilişkisinin çocuğun motivasyon düzeyi ile ilişkisini doğrudan inceleyen çalışmaya rastlanmamıştır. Bu nedenle bu araştırma okul öncesi dönemdeki çocukların baba-çocuk ilişkisi ile motivasyon düzeyleri arasındaki ilişkiyi incelemek amacıyla planlanmıştır. Çalışmada ayrıca baba-çocuk ilişkisi babaya ait demografik değişkenlere göre de incelenmiştir. Araştırma yurt içinde baba-çocuk ilişkisinin çocuğun motivasyon düzeyi üzerindeki etkisinin inceleyen ilk çalışma olması açısından önem taşımaktadır. Çalışmanın bundan sonraki yapılacak araştırmalara ve eğitim programlarına 1 şı tutacağı düşünülmektedir.

\section{YÖNTEM}

\section{Araştırmanın Modeli}

Araştırma genel tarama modelindedir. Bu model çok sayıda elemanı barından evrenden, evren ile ilgili genel bir yargıya varabilmek için evrenin tümü ya da ondan alınacak bir grup, örnek ya da örneklem üzerinde yapılan tarama çalışmalarıdır. Genel tarama modelleri kullanılarak tekil ya da ilişkisel taramalar yapılabilmektedir. İlişkisel tarama modelleri, iki ya da daha çok sayıdaki değişken arasında birlikte değişim varlığını ve/veya derecesini belirlemeyi amaçlamaktadır (Karasar, 2014, s. 79-80). Okul öncesi dönem çocuklarının baba-çocuk ilişkileri bazı değişkenlere ve çocukların motivasyon düzeylerine göre inceleneceği için ilişkisel tarama modeli seçilmiştir.

\section{Evren ve Örneklem}

Araştırmanın evreni, 2018-2019 eğitim öğretim yılında Diyarbakır ili Silvan ilçesinde Milli Eğitim Bakanlığı bünyesindeki ilkokula bağlı anasınıfları ve bağımsız anaokullarında öğrenim gören 48-72 aylık çocuklardan oluşmaktadır. Evren; tüm varlıkları ve olayları içeren bir sistemdir. Üzerinde araştırma yapılacak olan, belirli bir tanıma uyan ve araştırma sonuçlarının genellenmek istendiği birimler bütünüdür (Arıkan, 2011, s. 16).

Araştırmanın örneklemini evrenden 2441 tesadüfî küme örnekleme formülü kullanılarak belirlenmiş 4872 aylık 331 çocuk oluşturmaktadır. Veri toplanacak kümeler belirlenirken ilkokula bağlı anasınıfları ve anaokulları dengeli bir şekilde seçilmiş bunun yanında okulun bulunduğu mahallenin sosyo-ekonomik düzeyi de seçilen kümelerin kapsayıcı olması açısından dikkate alınmıştır. 
Örneklemi oluşturan çocukların \%52'si (n=172) erkek; \%48'i (n=159) kızdır. Çocukların babalarının yaşlarına göre dağılımları incelendiğinde çocukların \%60.4'ünün $(\mathrm{n}=200)$ babası 30-39; \%25.1'inin $(n=83)$ babası 40-49; \%10.3'ünün $(n=34)$ babası $20-29$ yaş aralığında; \%4.2'sinin $(n=14)$ babası 50 yaşın üzerindedir. Çocukların \%28.1'inin $(\mathrm{n}=93)$ babası lise, \%22.6'sının $(\mathrm{n}=63)$ babası ön lisans ve üstü, $\% 18.7$ 'sinin $(\mathrm{n}=62)$ ortaokul, \%16.6'sının $(\mathrm{n}=55)$ ilkokul mezunudur. Ayrıca çocukların \%8.2'sinin $(n=27)$ babası okur-yazar, \%5.7'sinin $(n=19)$ ise okur-yazar değildir. Çocuklarının \%57.4'ünün $(n=190)$ babası serbest meslekle, \%15.7' $\operatorname{sinin}(\mathrm{n}=52)$ babas1 profesyonel-yar1 profesyonel bir meslek grubunda (doktor, öğretmen, asker, polis), \%13.6'sının ( $\mathrm{n}=45)$ babası işçi, \%7.9'unun $(\mathrm{n}=26)$ babası işsiz, $\% 5.4$ 'ünün $(\mathrm{n}=18)$ babası memurdur.

\section{Veri Toplama Araçları}

Örneklemin demografik özelliklerini öğrenmeye yönelik araştırmacının geliştirdiği "Genel Bilgi Formu", çocukların motivasyon düzeylerini ölçmek için "Okul Öncesi Çocuklar İçin Motivasyon Ölçeği”" ve baba-çocuk ilişkisini ölçmek için "Çocuk Ebeveyn İlişki Ölçeği (Baba Formu)" kullanılmıştır. Araştırmada kullanılan ölçekler için gerekli izinler alınmıştır.

\section{Genel Bilgi Formu}

Babanın yaşı, babanın öğrenim durumu ve babanın mesleği bilgilerinin öğrenilmesine yönelik maddeleri içermektedir.

\section{Okul Öncesi Çocuklar İçin Motivasyon Ölçeği (The Dimensions of Mastery Questionnaire DMQ18)}

Morgan ve ark. (1993)'nın 30 yıldır geliştirmeye çalıştıkları bir ölçektir. 1997 ile 2014 yılları arasında DMQ17 sürümüyle kullanılan ölçek, Morgan ve Jozsa (2015)'nın değişik yaş grupları ve kültürlerde yaptıkları uyarlamalardan ulaştıkları verilere dayanarak revize edilip, DMQ18 sürümüne ilişkin geçerlik ve güvenirlik çalışmaları yapılmıştır. Motivasyon Ölçeği (DMQ18) yeni doğan, okul öncesi ve okul çağı çocuklar için revize edilmiştir. Okul Öncesi Motivasyon Ölçeği (DMQ18), bilişsel sebat, kaba motor sebat, yetişkinlerle sosyal sebat, çocuklarla sosyal sebat, üst düzey memnuniyet, olumsuz tepki ve genel yeterlilik olarak adlandırılan 7 alt boyut ve 39 madde içermektedir. 5'li Likert tipindeki ölçeğin maddeleri $1=$ Hiç onun gibi değil ile 5=Tam onun gibi arasında yanıtlanacak şekilde düzenlenmiştir. Çocuklar adına öğretmenleri doldurmaktadır. Ölçekten alınan puanların artması motivasyon düzeyinin artmasını ifade etmektedir. Ölçeğin yurt içinde uyarlamasını Özbey ve Dağlığglu (2017) yapmıştır.

Uyarlama çalışmasında dil geçerliği için 6 dil uzmanı ölçeğin orijinalini İngilizce'den Türkçe'ye ve Türkçe'den İngilizce'ye çevirmiştir. Bu çeviriler sonucunda ölçeğin orijinal halindeki maddeler ile tutarlı olduğu görülmüştür. Ölçeğin Sperman Brown İki Yarı Test güvenirliği katsayıları ise .77 ile .90 arasında değişiklik göstermektedir. Ölçeğin test tekrar test güvenirliği .85'dir. Ölçeğin Cronbach Alpha güvenirlik katsayıları, bilişsel sebat alt boyutunda .90; kaba motor sebat alt boyutunda .85; yetişkinlerle sosyal sebat alt boyutunda .88; çocuklarla sosyal sebat alt boyutunda .86; üst düzey memnuniyet alt boyutunda .65, olumsuz tepki alt boyutunda .79 ve genel yeterlilik alt boyutunda .94'dür (Özbey, 2018a).

“Okul Öncesi Çocuklar İçin Motivasyon Ölçeği” için Ankara örneklemindeki okul öncesi eğitim kurumlarında öğrenim gören 36-72 aylık 401 çocuk ile tekrar geçerlik güvenirlik çalışması Özbey (2018b) tarafından tekrar yapılmıştır. Ölçeğin Doğrulayıcı Faktör Analizi ile 7 faktörlü yapısı doğrulanmıştır Ölçeğin Cronbach Alpha güvenirlik katsayıları, bilişsel sebat alt boyutunda .91; kaba motor sebat alt boyutunda .88; yetişkinlerle sosyal sebat alt boyutunda .90; çocuklarla sosyal sebat alt boyutunda .87; üst düzey memnuniyet alt boyutunda .87; olumsuz tepki alt boyutunda .81 ve genel yeterlilik alt boyutunda .93'dür (Özbey, 2018b).

\section{Çocuk Ebeveyn İlişki Ölçeği (Baba Formu)}

Pianta (1992), çocuğun annesi ve babası ile ilişkisini belirlemek için 4,5-5,5 yaş aralığında çocuğu olan 714 ebeveynden veri toplayarak bu ölçeği geliştirmiştir. Ölçek orjinalinde olumlu ilişski, çatışma ve bağlanma alt boyutlarından ve 30 maddeden oluşmaktadır. 5'li Likert tipindeki ölçeğin maddeleri (1) Kesinlikle uygun değil ile (5) Kesinlikle çok uygun arasında yanıtlanacak şekilde düzenlenmiştir. Ölçekteki bazı ifadeler olumlu bazıları ise olumsuzdur. Olumlu olan maddeler tersine puanlanmaktadır. 
“(1) Kesinlikle uygun değil” 5 puan, “(5) kesinlikle çok uygun” 1 puandır. Ölçekten alınan puanın yüksek olması olumsuz ilişki, düşük olması olumlu ilişki anlamına gelmektedir. Ölçekten alınabilecek en düşük toplam puan 23 ile 115 puan arasında değişmektedir (Uzun ve Baran, 2015).

Pianta (1992) tarafından geliştirilen ölçeğin Türkçe uyarlama, geçerlik ve güvenirlik çalışmasını Uzun (2015) yapmıştır. Bu bağlamda ölçeğin dil geçerliği, kapsam geçerliği, yapı geçerliği ve güvenirlik çalışmaları yapılmıştır. Ölçeğin babalara yönelik uyarlamasında 23 madde ve üç alt boyut bulunmaktadır. Yapılan istatistiksel analizler sonucu ölçekteki Cronbach Alpha güvenirlik katsayıları olumlu ilişkiler alt boyutunda .76, uyumsuzluk alt boyutunda .61, çatışma alt boyutunda .62 ve maddelerin toplamında .71 olarak saptanmıştır (Uzun ve Baran, 2015).

\section{Verilerin Analizi}

Verilerin kodlanması ve istatistiksel analizleri SPSS 20.00 for Windows 11.5 paket programında yapılmışırı. Nonparametrik dağılım gösteren bağımsız ikiden fazla grup arasında farkın önemliliği Kruskal Wallis testi ile araştırılmıştır. Kruskal Wallis testinde anlamlı sonuç elde edildiğinde anlamlılığın hangi gruplar arasında olduğunu saptamak için post-hoc test olarak Mann-Whitney U testi yapılmıştır.

Değişkenler nonparametrik olduğu için gruplar arası korelasyon Spearman korelasyon testi ile değerlendirilmiştir. Korelasyon katsayıları $\mathrm{r}<0,30$ olması durumunda düşük ilişki; $0,30<\mathrm{r}<0,70$ olması durumunda orta düzeyde ilişki; $0,70<\mathrm{r}$ olması durumunda yüksek ilişki olarak yorumlanmıştır. Sonuçlar $\% 95$ güven aralığında değerlendirilerek $\mathrm{p}<0,05$ istatiksel anlamlılık olarak hesaplanmıştır.

\section{BULGULAR}

Bu bölümde araştırmanın amaçları doğrultusunda baba- çocuk ilişkisinin babanın yaşı, öğrenim durumu ve mesleği değişkenlerine göre farklılaşıp farklılaşmadığına ve çocukların motivasyon düzeyi ile babaçocuk ilişkisine yönelik bulgulara yer verilmiştir.

\section{Baba- Çocuk İlişkisi / Baba Yaşı}

Tablo 1. Baba Yaşı Değişkenine Göre Babaların "Çocuk Ebeveyn İlişsi Ölçeği (Baba Formu)” nden Aldrkları Puanlara İlişkin Kruskal-Wallis Testi

\begin{tabular}{|c|c|c|c|c|c|c|c|}
\hline & \multirow[b]{2}{*}{ Baba Yaşı } & \multirow[b]{2}{*}{$\mathrm{N}$} & \multicolumn{2}{|c|}{ Baba Çocuk İlişkisi } & \multirow[b]{2}{*}{$\mathrm{X}^{2}$} & \multirow[b]{2}{*}{$P$} & \multirow[b]{2}{*}{$\begin{array}{c}\text { Farkın } \\
\text { Kaynağ1 } \\
\text { Mann } \\
\text { Whitney U }\end{array}$} \\
\hline & & & Sira Ort. & $\mathrm{Sd}$ & & & \\
\hline \multirow[t]{4}{*}{ Olumlu İlişki } & $1.20-29$ & 34 & 167.56 & 3 & 8.724 & 0.033* & \\
\hline & $2.30-39$ & 200 & 161.89 & & & & $4>1$ \\
\hline & $3.40-49$ & 83 & 174.28 & & & & $4>2$ \\
\hline & $4.50+$ & 14 & 171.93 & & & & \\
\hline \multirow[t]{4}{*}{ Uyumsuzluk } & $1.20-29$ & 34 & 167.56 & 3 & 1.058 & 0.787 & \\
\hline & $2.30-39$ & 200 & 161.89 & & & & \\
\hline & $3.40-49$ & 83 & 174.28 & & & & \\
\hline & $4.50+$ & 14 & 171.93 & & & & \\
\hline \multirow[t]{4}{*}{ Çatışma } & $1.20-29$ & 34 & 151.09 & 3 & 1.560 & 0.668 & \\
\hline & $2.30-39$ & 200 & 164.95 & & & & \\
\hline & $3.40-49$ & 83 & 171.99 & & & & \\
\hline & $4.50+$ & 14 & 181.68 & & & & \\
\hline \multirow[t]{4}{*}{ Toplam } & $1.20-29$ & 34 & 160.87 & 3 & 7.625 & 0.054 & \\
\hline & $2.30-39$ & 200 & 158.82 & & & & \\
\hline & $3.40-49$ & 83 & 175.17 & & & & \\
\hline & $4.50+$ & 14 & 226.68 & & & & \\
\hline
\end{tabular}

Tablo 1 incelendiğinde babaların yaşlarına göre, "Çocuk Ebeveyn İlişki Ölçeği (Baba Formu)” Olumlu İlişki alt boyutundan aldıkları puanlar arasında anlamlı fark bulunmaktadır $\left(\mathrm{X}^{2}=8.724 \mathrm{p}<0.05\right)$. 
Farklılığın hangi gruplar arasında olduğunu saptamak için Mann Whitney U Testi ile ikili karşılaştırma yapılmıştır. Mann Whitney U Testi sonucunda Olumlu İlişki alt boyutunda;

- 20-29 yaş grubunda olan babaların (sıra ort. $=21.25$ ) 50 ve üzeri yaş grubunda olan babalara (sıra ort. $=32.39$ ) göre,

- 30-39 yaş grubunda olan babaların (sıra ort.=104.17) 50 ve üzeri yaş grubunda olan babalara (sıra ort.=155.11) göre baba-çocuk ilişki düzeylerinin daha yüksek olduğu saptanmıştır.

Diğer alt boyutlarda ve ölçek toplamında baba yaşına göre alınan puanlar arasında anlamlı fark bulunmamaktadır $\left(\mathrm{X}_{\mathrm{U}}^{2}=1.058 \mathrm{p}>0.05 ; \mathrm{X}_{\mathrm{C}}=1.560 \mathrm{p}>0.05 ; \mathrm{X}_{\mathrm{T}}^{2}=7.625 \mathrm{p}>0.05\right)$.

\section{Baba- Çocuk İlişkisi / Baba Öğrenim Durumu}

Tablo 2. Baba Öğrenim Durumu Değişkenine Göre Babaların "Çocuk Ebeveyn İlişki Ölçeği (Baba Formu)" nden Aldıkları Puanların Karşılaştırılmasına İlişkin Kruskal-Wallis Testi

\begin{tabular}{|c|c|c|c|c|c|c|c|}
\hline & \multirow[b]{2}{*}{$\begin{array}{l}\text { Baba Öğrenim } \\
\text { Durumu }\end{array}$} & \multirow[b]{2}{*}{$\mathrm{N}$} & \multicolumn{2}{|c|}{ Baba Çocuk İlişkisi } & \multirow[b]{2}{*}{$X^{2}$} & \multirow[b]{2}{*}{$\mathrm{P}$} & \multirow[b]{2}{*}{$\begin{array}{c}\text { Farkın } \\
\text { Kaynağ1 } \\
\text { Mann } \\
\text { Whitney U }\end{array}$} \\
\hline & & & Sira Ort. & $\mathrm{Sd}$ & & & \\
\hline \multirow[t]{6}{*}{ Olumlu İlişki } & 1.Okur-yazar değil & 19 & 189.37 & 5 & 6.026 & 0.304 & \\
\hline & 2.Okur-yazar & 27 & 175.48 & & & & \\
\hline & 3.İlkokul mezunu & 55 & 185.69 & & & & \\
\hline & 4.Ortaokul mezunu & 62 & 149.35 & & & & \\
\hline & 5.Lise mezunu & 93 & 160.30 & & & & \\
\hline & $\begin{array}{l}\text { 6.Önlisans ve üstü } \\
\text { mezunu }\end{array}$ & 75 & 163.05 & & & & \\
\hline \multirow[t]{6}{*}{ Uyumsuzluk } & 1.Okur-yazar değil & 19 & 178.26 & 5 & 3.380 & 0.642 & \\
\hline & 2.Okur-yazar & 27 & 153.54 & & & & \\
\hline & 3.İlkokul mezunu & 55 & 164.78 & & & & \\
\hline & 4.Ortaokul mezunu & 62 & 180.35 & & & & \\
\hline & 5.Lise mezunu & 93 & 167.85 & & & & \\
\hline & $\begin{array}{l}\text { 6.Önlisans ve üstü } \\
\text { mezunu }\end{array}$ & 75 & 154.11 & & & & \\
\hline \multirow[t]{6}{*}{ Çatışma } & 1.Okur-yazar değil & 19 & 225.21 & 5 & 14.588 & 0.012* & $1>2$ \\
\hline & 2.Okur-yazar & 27 & 152.02 & & & & $1>3$ \\
\hline & 3.İlkokul mezunu & 55 & 157.37 & & & & $1>4$ \\
\hline & 4.Ortaokul mezunu & 62 & 175.58 & & & & $1>5$ \\
\hline & 5.Lise mezunu & 93 & 175.80 & & & & $1>6$ \\
\hline & $\begin{array}{l}\text { 6.Önlisans ve üstü } \\
\text { mezunu }\end{array}$ & 75 & 142.29 & & & & $\begin{array}{l}4>6 \\
5>6\end{array}$ \\
\hline \multirow[t]{6}{*}{ Toplam } & 1.Okur-yazar değil & 19 & 212.32 & 5 & 6.999 & 0.221 & \\
\hline & 2.Okur-yazar & 27 & 154.67 & & & & \\
\hline & 3.İlkokul mezunu & 55 & 167.18 & & & & \\
\hline & 4.Ortaokul mezunu & 62 & 171.06 & & & & \\
\hline & 5.Lise mezunu & 93 & 168.14 & & & & \\
\hline & $\begin{array}{l}\text { 6.Önlisans ve üstü } \\
\text { mezunu }\end{array}$ & 75 & 150.64 & & & & \\
\hline
\end{tabular}

$* \mathrm{p}<0.05$

Tablo 2 incelendiğinde babaların öğrenim durumlarına göre, "Çocuk Ebeveyn İlişki Ölçeği (Baba Formu)" Çatışma alt boyutundan aldıkları puanlar arasında anlamlı fark bulunmaktadır $\left(\mathrm{X}^{2}=14.588\right.$ $\mathrm{p}<0.05)$. Farklılığın hangi gruplar arasında olduğunu saptamak için Mann Whitney U Testi ile ikili karşılaştırma yapılmıştır. Mann Whitney U Testi sonucunda Çatışma alt boyutunda;

- okur-yazar olan babaların (sira ort.=19.17) okur-yazar olmayan babalara (sıra ort.=29.66) göre,

- $\quad$ ilkokul mezunu olan babaların (sira ort.=34.19) okur-yazar olmayan babalara (sira ort.=47.08) göre, 
- ortaokul mezunu olan babaların (sıra ort. $=37.79)$ okur-yazar olmayan babalara (sira ort.=51.47) göre,

- lise mezunu olan babaların (sıra ort.=53.61) okur-yazar olmayan babalara (sıra ort.=70.63) göre,

- önlisans ve üstü mezunu olan babaların (sıra ort.=42.72) okur-yazar olmayan babalara (sıra ort.=66.37) göre,

- önlisans ve üstü mezunu olan babaların (sıra ort.=62.47) ortaokul mezunu olan babalara (sıra ort. $=76.90)$ göre,

- önlisans ve üstü mezunu olan babaların (sıra ort.=74.84) lise mezunu olan babalara (sıra ort.=92.29) göre baba-çocuk ilişki düzeylerinin anlamlı derecede yüksek olduğu saptanmıştır.

Diğer alt boyutlarda ve ölçek toplamında baba öğrenim durumu değişkenine göre alınan puanlar arasında anlamlı fark bulunmamaktadır $\left(\mathrm{X}^{2}{ }_{\mathrm{O} i}=6.026 \mathrm{p}>0.05 ; \mathrm{X}_{\mathrm{U}}^{2}=3.380 \mathrm{p}>0.05 ; \mathrm{X}_{\mathrm{T}}{ }^{2}=6.999 \mathrm{p}>0.05\right)$

\section{Baba-Çocuk İlişkisi / Baba Mesleği}

Tablo 3. Baba Mesleği Değişkenine Göre Babaların "Çocuk Ebeveyn İlişki Ölçeği (Baba Formu)" nden Aldıkları Puanlara İlişkin Kruskal-Wallis Testi

\begin{tabular}{|c|c|c|c|c|c|c|c|}
\hline & \multirow[b]{2}{*}{ Baba Mesleği } & \multirow[b]{2}{*}{$\mathrm{N}$} & \multicolumn{2}{|c|}{ Baba Çocuk İlişkisi } & \multirow[b]{2}{*}{$X^{2}$} & \multirow[b]{2}{*}{$\mathrm{P}$} & \multirow[b]{2}{*}{$\begin{array}{c}\text { Farkın } \\
\text { Kaynağ1 } \\
\text { Mann } \\
\text { Whitney U }\end{array}$} \\
\hline & & & Sira Ort. & $\mathrm{Sd}$ & & & \\
\hline \multirow[t]{6}{*}{ Olumlu İlişki } & 1.Profesyonel-Yarı & 52 & 149.13 & 4 & 2.512 & 0.642 & \\
\hline & Profesyonel Meslek & & & & & & \\
\hline & 2.Memur & 18 & 183.69 & & & & \\
\hline & 3.İşçi & 45 & 165.18 & & & & \\
\hline & 4.Serbest Meslek & 190 & 168.05 & & & & \\
\hline & 5.Çalışmiyor & 26 & 173.96 & & & & \\
\hline \multirow[t]{6}{*}{ Uyumsuzluk } & 1.Profesyonel-Yarı & 52 & 130.13 & 4 & 13.400 & $0.009 *$ & \\
\hline & Profesyonel Meslek & & & & & & \\
\hline & 2.Memur & 18 & 175.64 & & & & $4>1$ \\
\hline & 3.İşçi & 45 & 145.47 & & & & $4>3$ \\
\hline & 4.Serbest Meslek & 190 & 179.47 & & & & \\
\hline & 5.Çalışmiyor & 26 & 168.19 & & & & \\
\hline \multirow[t]{6}{*}{ Çatışma } & 1.Profesyonel-Yarı & 52 & 119.95 & 4 & 17.583 & 0.001* & \\
\hline & Profesyonel Meslek & & & & & & $2>1$ \\
\hline & 2.Memur & 18 & 174.31 & & & & $4>1$ \\
\hline & 3.İşçi & 45 & 152.46 & & & & $5>1$ \\
\hline & 4.Serbest Meslek & 190 & 180.48 & & & & \\
\hline & 5.Çalışmiyor & 26 & 169.98 & & & & \\
\hline \multirow[t]{6}{*}{ Toplam } & 1.Profesyonel-Yarı & 52 & 124.24 & 4 & 15.528 & 0.004* & \\
\hline & Profesyonel Meslek & & & & & & $2>1$ \\
\hline & 2.Memur & 18 & 175.33 & & & & $4>1$ \\
\hline & 3.İşçi & 45 & 148.76 & & & & $5>1$ \\
\hline & 4.Serbest Meslek & 190 & 179.50 & & & & \\
\hline & 5.Çalışmıyor & 26 & 174.25 & & & & \\
\hline
\end{tabular}

*p<0.05

Tablo 3 incelendiğinde babaların mesleklerine göre, "Çocuk Ebeveyn İlişki Ölçeği (Baba Formu)" Uyumsuzluk, Çatışma alt boyutlarında ve ölçek toplamında aldıkları puanlar arasında anlamlı fark bulunmaktadır $\left(\mathrm{X}_{\mathrm{U}}^{2}=13.400 \mathrm{p}<0.05 ; \mathrm{X}_{\mathrm{C}}^{2}=17.583 \mathrm{p}<0.05 ; \mathrm{X}_{\mathrm{T}}^{2}=15.528 \mathrm{p}<0.05\right)$. Farklılığın hangi gruplar arasında olduğunu saptamak için Mann Whitney U Testi ile ikili karşılaştırma yapılmıştır. Mann Whitney U Testi sonucunda;

Olumlu İlişki alt boyutunda baba mesleğine göre alınan puanlar arasında anlamlı fark bulunmamaktadır $\left(\mathrm{X}^{2}=2.512 \mathrm{p}>0.05\right)$. 
Uyumsuzluk alt boyutunda;

- profesyonel-yarı profesyonel meslek grubunda olan babaların (sira ort.=93.54) serbest meslek grubunda olan babalara (sıra ort.=129.15) göre,

- işçi meslek grubunda olan babaların (sıra ort.=98.34) serbest meslek grubunda olan babalara (sıra ort.=122.66) göre baba-çocuk ilişki düzeyi puanlarının anlamlı derecede yüksek olduğu saptanmiştır $(\mathrm{p}<0.05)$.

Çatışma alt boyutunda;

- profesyonel-yarı profesyonel meslek grubunda olan babaların (sira ort.=32.66) memur grubunda olan babalara (sıra ort. $=43.69$ ) göre,

- profesyonel-yarı profesyonel meslek grubunda olan babaların (sira ort.=87.00) serbest meslek grubunda olan babalara (sıra ort.=130.94) göre,

- profesyonel-yarı profesyonel meslek grubunda olan babaların (sıra ort.=35.15) çalışmayan babalara (sıra ort.=48.19) göre baba-çocuk ilişki düzeyi puanlarının anlamlı derecede yüksek olduğu saptanmıştır $(\mathrm{p}<0.05)$.

Ölçek toplamında;

- profesyonel-yarı profesyonel meslek grubunda olan babaların (sıra ort.=32.59) memur grubunda olan babalara (

- profesyonel-yarı profesyonel meslek grubunda olan babaların (sıra ort.=90.29) serbest meslek grubunda olan babalara (sıra ort.=130.04) göre,

- profesyonel-yarı profesyonel olan babaların (sıra ort. $=35.40$ ) çalışmayan babalara (sıra ort.=47.69) göre baba-çocuk ilişki düzeyi puanlarının anlamlı derecede yüksek olduğu saptanmıştır $(\mathrm{p}<0.05)$.

\section{Motivasyon/Baba-Çocuk İlișkisi}

Tablo 4. Çocukların "Okul Öncesi Çocuklar İçin Motivasyon Ölçeği” nden Aldıkları Puanlarla Babaların "Çocuk Ebeveyn İlişki Ölçeği (Baba Formu)" nden Aldıkları Puanlara İlişkin Spearman Korelasyon Testi

\begin{tabular}{|c|c|c|c|}
\hline & & \multicolumn{2}{|c|}{ Motivasyon Ölçeği-Baba Çocuk Ölçeği Korelasyonu } \\
\hline & & $\mathrm{R}$ & $\mathrm{P}$ \\
\hline \multirow[t]{7}{*}{ Olumlu İlişki } & Bilişsel Sebat & -.286 & $<0.001 *$ \\
\hline & Kaba Motor Sebat & -.298 & $<0.001 *$ \\
\hline & Yetişkinlerle Sosyal Sebat & -.302 & $<0.001 *$ \\
\hline & Çocuklarla Sosyal Sebat & -.249 & $<0.001 *$ \\
\hline & Üst Düzey Memnuniyet & -.257 & $<0.001 *$ \\
\hline & Olumsuz Tepki & -.204 & $<0.001 *$ \\
\hline & Genel Yeterlilik & -.341 & $<0.001 *$ \\
\hline \multirow[t]{7}{*}{ Uyumsuzluk } & Bilişsel Sebat & -.319 & $<0.001 *$ \\
\hline & Kaba Motor Sebat & -.287 & $<0.001 *$ \\
\hline & Yetişkinlerle Sosyal Sebat & -.252 & $<0.001 *$ \\
\hline & Çocuklarla Sosyal Sebat & -.309 & $<0.001 *$ \\
\hline & Üst Düzey Memnuniyet & -.187 & $<0.001 *$ \\
\hline & Olumsuz Tepki & -.163 & $<0.001 *$ \\
\hline & Genel Yeterlilik & -.305 & $<0.001 *$ \\
\hline \multirow[t]{7}{*}{ Çatışma } & Bilişsel Sebat & -.309 & $<0.001 *$ \\
\hline & Kaba Motor Sebat & -.302 & $<0.001 *$ \\
\hline & Yetişkinlerle Sosyal Sebat & -.272 & $<0.001 *$ \\
\hline & Çocuklarla Sosyal Sebat & -.302 & $<0.001 *$ \\
\hline & Üst Düzey Memnuniyet & -.233 & $<0.001 *$ \\
\hline & Olumsuz Tepki & -.203 & $<0.001 *$ \\
\hline & Genel Yeterlilik & -.293 & $<0.001 *$ \\
\hline
\end{tabular}




\begin{tabular}{|c|c|c|c|}
\hline Toplam & $\begin{array}{l}\text { Bilişsel Sebat } \\
\text { Kaba Motor Sebat } \\
\text { Yetişkinlerle Sosyal Sebat } \\
\text { Çocuklarla Sosyal Sebat } \\
\text { Üst Düzey Memnuniyet } \\
\text { Olumsuz Tepki } \\
\text { Genel Yeterlilik }\end{array}$ & $\begin{array}{l}-.402 \\
-.373 \\
-.360 \\
-.374 \\
-.300 \\
-.253 \\
-.401\end{array}$ & $\begin{array}{l}<0.001 * \\
<0.001 * \\
<0.001 * \\
<0.001 * \\
<0.001 * \\
<0.001 * \\
<0.001 *\end{array}$ \\
\hline
\end{tabular}

r: korelasyon katsayıs1

$* \mathrm{p}<0.05$

Tablo 4'e göre çocukların "Okul Öncesi Çocuklar için Motivasyon Ölçeği” nin Bilişsel Sebat (r=-.402), Kaba Motor Sebat (r=-.373), Yetişkinlerle Sosyal Sebat $(\mathrm{r}=-.360)$, Çocuklarla Sosyal Sebat $(\mathrm{r}=-.374)$, Üst Düzey Memnuniyet (r=-.300), Olumsuz. Tepki $(\mathrm{r}=-.253)$ ve Genel Yeterlilik $(\mathrm{r}=-.401)$ alt ölçekleri ile "Çocuk Ebeveyn İlişki Ölçeği (Baba Formu)" ölçeğin toplamından aldıkları puanlar arasında anlamlı, negatif yönde ve orta düzeyde ilişki olduğu saptanmıştır $(\mathrm{p}<0.01)$.

"Çocuk Ebeveyn İlişki Ölçeği (Baba Formu)"nden alınan puanlar arttıkça baba-çocuk ilişkisindeki problem artmakta, puanlar azaldıkça ilişkideki problem de azalmaktadır. Bunun tersine "Okul Öncesi Çocuklar için Motivasyon Ölçeğì" nden çocukların aldıkları puanlar arttıkça motivasyon düzeyi artmakta, puanlar azaldıkça motivasyon düzeyi azalmaktadır. Bu nedenle baba-çocuk iliş̧kisinde daha az probleme sahip babaların çocuklarının motivasyon düzeylerinin yüksek olduğunu söyleyebilmek mümkündür. Tersine baba-çocuk ilişkisinde problemler arttıkça çocukların da motivasyon düzeyleri azalmaktadır.

Tablo 5. Baba-Çocuk İlişkisinin Motivasyon Düzeyi Üzerindeki Etkisini Belirlemeye Yönelik Basit Doğrusal Regresyon Analizi

\begin{tabular}{|c|c|c|c|c|c|c|c|}
\hline & & $\mathrm{R}$ & $\mathrm{R}^{2}$ & $\begin{array}{c}\text { Standardize } \\
\text { Edilmiş B }\end{array}$ & $\mathrm{T}$ & $\mathrm{F}$ & $\mathrm{P}$ \\
\hline \multirow[t]{7}{*}{ Olumlu İlişki } & Bilişsel Sebat & 0.460 & 0.212 & -.460 & -9.394 & 88.248 & $<0.001 *$ \\
\hline & Kaba Motor Sebat & 0.482 & 0.232 & -.482 & -9.970 & 99.397 & $<0.001 *$ \\
\hline & Yetişkinlerde Sosyal Sebat & 0.444 & 0.197 & -.444 & -8.976 & 80.562 & $<0.001 *$ \\
\hline & Çocuklarla Sosyal Sebat & 0.397 & 0.158 & -.397 & -7.848 & 61.585 & $<0.001 *$ \\
\hline & Üst Düzey Memnuniyet & 0.441 & 0.194 & -.441 & -8.909 & 79.375 & $<0.001 *$ \\
\hline & Olumsuz Tepki & 0.303 & 0.092 & -.303 & -5.757 & 33.144 & $<0.001 *$ \\
\hline & Genel Yeterlilik & 0.489 & 0.239 & -0.489 & -10.174 & 103.515 & $<0.001 *$ \\
\hline \multirow[t]{7}{*}{ Uyumsuzluk } & Bilişsel Sebat & 0.391 & 0.153 & -.391 & -7.700 & 59.292 & $<0.001 *$ \\
\hline & Kaba Motor Sebat & 0.358 & 0.128 & -.358 & -6.961 & 48.450 & $<0.001 *$ \\
\hline & Yetişkinlerle Sosyal Sebat & 0.289 & 0.084 & -.289 & -5.478 & 30.007 & $<0.001 *$ \\
\hline & Çocuklarla Sosyal Sebat & 0.346 & 0.119 & -.346 & -6.679 & 44.614 & $<0.001 *$ \\
\hline & Üst Düzey Memnuniyet & 0.286 & 0.082 & -.286 & -5.414 & 29.311 & $<0.001 *$ \\
\hline & Olumsuz Tepki & 0.235 & 0.055 & -.235 & -4.377 & 19.162 & $<0.001 *$ \\
\hline & Genel Yeterlilik & 0.366 & 0.134 & -0.366 & -7.126 & 50.778 & $<0.001 *$ \\
\hline \multirow[t]{7}{*}{ Çatışma } & Bilişsel Sebat & 0.354 & 0.125 & -.354 & -6.868 & 47.173 & $<0.001 *$ \\
\hline & Kaba Motor Sebat & 0.346 & 0.119 & -.346 & -6.680 & 44.620 & $<0.001 *$ \\
\hline & Yetişkinlerle Sosyal Sebat & 0.304 & 0.093 & -.304 & -5.798 & 33.616 & $<0.001 *$ \\
\hline & Çocuklarla Sosyal Sebat & 0.337 & 0.114 & -.337 & -6.502 & 42.273 & $<0.001 *$ \\
\hline & Üst Düzey Memnuniyet & 0.328 & 0.107 & -.328 & -6.290 & 39.568 & $<0.001 *$ \\
\hline & Olumsuz Tepki & 0.226 & 0.051 & -.226 & -4.200 & 17.643 & $<0.001 *$ \\
\hline & Genel Yeterlilik & 0.355 & 0.126 & -0.355 & -6.897 & 47.570 & $<0.001 *$ \\
\hline \multirow[t]{7}{*}{ Toplam } & Bilişsel Sebat & 0.534 & 0.286 & -.534 & -11.470 & 131.572 & $<0.001 *$ \\
\hline & Kaba Motor Sebat & 0.530 & 0.281 & -.530 & -11.331 & 128.380 & $<0.001 *$ \\
\hline & Yetişkinlerle Sosyal Sebat & 0.466 & 0.217 & -.466 & -9.557 & 91.334 & $<0.001 *$ \\
\hline & Çocuklarla Sosyal Sebat & 0.476 & 0.227 & -.476 & -9.820 & 96.439 & $<0.001 *$ \\
\hline & Üst Düzey Memnuniyet & 0.472 & 0.222 & -.472 & -9.703 & 94.147 & $<0.001 *$ \\
\hline & Olumsuz Tepki & 0.340 & 0.115 & -.340 & -6.552 & 42.928 & $<0.001 *$ \\
\hline & Genel Yeterlilik & 0.540 & 0.292 & -0.540 & -11.649 & 135.705 & $<0.001 *$ \\
\hline
\end{tabular}


Tablo 5' e göre baba-çocuk ilişkisinin olumlu olması çocukların bilişsel sebat düzeyini \%28 oranında, kaba motor sebat düzeyini \%28 oranında, yetişkinlerle sosyal sebat düzeyini \%21 oranında, çocuklarla sosyal sebat düzeyini $\% 22$ oranında, üst düzey memnuniyet düzeyini $\% 22$ oranında, olumsuz tepki düzeyini \%11 oranında ve genel yeterlilik düzeyini \%29 oranında negatif yönde anlamlı yordamaktadır $(\mathrm{p}<0.01)$.

\section{TARTIŞMA VE SONUÇ}

Araştırma sonucunda babaların yaşlarına göre "Çocuk Ebeveyn İlişki Ölçeği (Baba Formu)" olumlu ilişski alt boyutundan aldıkları puanlar arasında $20-29$ ve 30-39 yaş grubundaki babaların, 50 ve üzeri yaş grubundaki babalara göre baba-çocuk ilişki düzeyleri anlamlı derecede yüksek bulunurken, diğer alt boyutlarda ve ölçek toplamında baba yaşına göre alınan puanlar arasında anlamlı fark bulunmamaktadır (Tablo 1). Özkan (2014)'ın yaptığı çalışmada 36-40 yaş aralığındaki babaların, 26-30, 31-35 ve 41-45 yaş aralığındaki babalara göre çocuklarıyla daha olumlu ilişkiler kurdukları sonucuna ulaşılmıştır. Kuruçırak (2010) ve Telli (2014) çalışmalarında babaların babalık rolü algısının babaların yaşına göre anlamlı farklılık göstermediğini saptamışlardır. Marsiglio (1991) babaların yaşı ilerledikçe, çocuklarının eğitim ve bakımına katılma konusunda isteklerinin arttığını saptamıştır (Aktaran Şahin ve Demiriz, 2014). Castillo, Welch ve Sarver (2010), genç babalara oranla yaşı büyük olan babaların çocuğun yaşamındaki rutin aktivitelere daha fazla katılım gösterdiğini saptamışlardır. Aksoy ve Tatlı (2019)'nın çalışmalarında babaların yaş ortalamaları yükseldikçe çocuklarıyla ilişkilerinin daha olumlu olduğu görülmüştür. Bulanda (2004) ise babaların yaşları arttıça çocuklarının eğitimine daha az katılım gösterdiğini saptamıştır. Literatürdeki çalışmalarda farklı sonuçlar görülmekle birlikte yapılan çalışmada baba yaşına ilişkin bulgular, çoğu alt boyutta ve ölçek toplamında baba-çocuk arasındaki ilişkinin baba yaşı değişkenine göre farklılık göstermediği şeklinde yorumlanabilir. Babanın yaşı ne olursa olsun çocuğun bakımında etkin olması, çocuğun eğitim sürecine dahil olması, çocuğuyla oyun oynayarak keyifli vakit geçirmesi ve aralarında sıcak bir ilişki kurulması gibi durumlar baba-çocuk ilişkisini etkilemekte ve bundan dolayı baba yaşının baba-çocuk ilişkisini etkilemesine yönelik olarak farklı sonuçlar çıktığı düşünülmektedir.

Babaların öğrenim durumlarına göre "Çocuk Ebeveyn İlişki Ölçeği (Baba Formu)" çatışma alt boyutundan alınan puanlar arasında anlamlı fark bulunurken, diğer alt boyutlarda ve ölçek toplamında baba öğrenim durumuna göre alınan puanlar arasında anlamlı fark bulunmamaktadır. Çatışma alt boyutunda, babaların öğrenim durumu yükseldikçe çocuklarıyla aralarındaki çatışmanın azaldığı saptanmıştır (Tablo 2). Özkan (2014), çalışmasında deney grubundaki babaların "Çocuk Ebeveyn İlişki Ölçeği”nden aldıkları puanlarda baba öğrenim durumuna göre anlamlı bir fark olmadığını saptamıştır. Flouri ve Buchanan (2003), yaptıkları çalı̧̧mada yükseköğrenim düzeyine sahip olan babaların çocuklarına karşı daha ilgili olduğunu saptamıştır. Nkwake (2009) çalışmasında eğitim düzeyi arttıkça baba-çocuk ilişkisi düzeyinin ve baba katılımının arttığı sonucuna ulaşmıştır. Şahin ve Demiriz (2014)'in çalışmasında babaların öğrenim durumunun artmasıyla aile katılımı ve babalık rolü algısının arttığı sonucu ortaya çıkmıştır. Özmert, Yurdakök ve Soysal (2001) tarafindan yapılan çalışmada anne öğrenim durumunun çocuğun başarısına dört-sekiz kat etkisi olurken baba öğrenim durumunun başarıya on kata kadar etkisinin olduğu sonucuna ulaşı1mıştır (Aktaran Poyraz, 2007). Literatürden belirtilen çalışmalarda birbirinden farklı sonuçlar görülmekle birlikte yapılan çalışmada çoğu alt boyutta ve ölçek toplamında baba öğrenim durumunun baba-çocuk ilişkisi üzerinde etkili olmadığı bulgusuna ulaşılmıştır. Öğrenim durumunun artmasının aradaki ilişkiye olumlu katkı sağlayacağı düşünülebilir ancak bazı babalar ögrenim durumu iyi olmasa dahi istek ve gayretleriyle öğrenim durumlarının yaratabileceği dezavantajları en aza indirgeyerek çocuklarına benzer deneyimleri yaşatmaktadır. Bundan dolayı çalışmaya dahil edilen babaların öğrenim durumunun çocuklarıyla ilişkilerini etkilemediği düşünülmektedir.

Babaların mesleklerine göre "Çocuk Ebeveyn İlişki Ölçeği (Baba Formu)" uyumsuzluk, çatışma alt boyutlarında ve ölçek toplamında aldıkları puanlar arasında profesyonel-yarı profesyonel meslek grubundaki babaların lehine anlamlı fark bulunurken, olumlu tepki alt boyutunda anlamlı fark bulunmamaktadır (Tablo 3). Poyraz (2007)'ın yaptığı çalışmada babaların meslek grupları yevmiyeli, işçi, memur, işveren ve diğer olarak kategorize edilmiş ve gruplar arasında "Babalık Rolü Algı Ölçeği" puanları açısından anlamlı farklılık saptanmamıştır. Özkan (2014), çalışmasında babaların öğrenim 
durumlarını serbest meslek, memur, işçi ve emekli olarak kategorize etmiş ve deney grubundaki babalar ve çocukları arasında babaların mesleklerine göre "Çocuk Ebeveyn İlişki Ölçeği” nin alt boyutlarında alınan puanlar arasında anlamlı bir fark saptamamıştır. Yapılan çalışmada baba-çocuk ilişkisinde anlamlı farklılı̆gı profesyonel-yarı profesyonel meslek grubunda olan babaların lehine olduğu saptanmıştır. Çalışmanın örnekleminde bu meslek grubundaki babaların maddi imkanlarının yeterliliğinden dolayı ev geçindirme kaygılarının olmayışı bu sayede çocuklarının ihtiyaçlarını yeteri kadar karşılayabildikleri, çocuklarına nitelikli ve düzenli zaman ayırabildikleri bunun yanında diğer meslek gruplarında çalışan ya da herhangi bir işte çalışamayan babaların maddi kaygılardan ve düzenli çalışma saatlerinin olmayışından dolayı çocuklarıyla sağlıklı ilişki kurmakta zorlandıkları bunlardan kaynaklı profesyonelyarı profesyonel meslek grubundaki babaların çocuklarıyla ilişkilerinin daha olumlu olduğu düşünülmektedir.

Çocukların "Okul Öncesi Çocuklar için Motivasyon Ölçeği” nin alt ölçeklerinden aldıkları puanlar "Çocuk Ebeveyn İlişki Ölçeği (Baba Formu)" nin alt ölçeklerinden ve ölçek toplamından aldıkları puanları negatif yönde anlamlı yordamaktadır (Tablo 4 ve Tablo 5). Benzer ölçeklerle yapılan çalışmalardan Tezci, Sezer, Gürgan ve Aktan (2015) tarafindan sosyal destek ve motivasyon üzerine yapılan çalışmada bireyin çevresinden yeteri kadar destek almasının motivasyon üzerindeki etkisinin olumlu olduğu görülmüştür. Gültekin Akduman ve Türkoğlu (2015)'nun çalışmasında babalık rolü algısının artmasıyla çocukların sosyal beceri düzeylerinin arttığı sonucuna ulaşılmıştır. Güzel (2019) yaptığı çalışmada ölçek genelinde baba-çocuk ilişkisi ile babalık rolü algısı arasındaki ilişkinin anlamlı ve orta düzeyli olduğunu saptamıştır. Özsoy Yanbak (2019)'ın çalışmasında baba-çocuk arasındaki olumlu ilişkinin çocuğun öz düzenleme becerilerine etkisinin olumlu yönde olduğu saptanmıştır. Yapılan çalışma ve diğer çalışmaların bulguları birlikte değerlendirildiğinde motivasyonun ve baba-çocuk ilişkisinin karşılıklı etkileşim içinde oldukları sonucu ortaya çıkmaktadır. Babasıyla sağlıklı ilişki kurması çocuğun kendisiyle barışık, sosyal ilişkilerinde başarılı, yüksek benlik saygısına sahip, iletişim kurabilme konusunda becerikli ve kendisini daha iyi ifade eden bir birey olmasını sağlamaktadır. Bununla birlikte arkadaşlarıyla uyumunun daha iyi olduğu, liderlik özelliklerini daha çok taşıdığı, eğitim sürecine daha çok katıldığı, etkinliklerde daha ilgili, hevesli ve başarılı olduğu bilinmektedir. Tüm bu özellikler dikkate alındığında sağlıklı baba-çocuk ilişkisinin çocuklarda eş zamanlı olarak içsel motivasyonu destekleyici etkisinin olduğu yorumunu yapabilmek mümkündür.

\section{ÖNERILER}

Araştırma sonuçları dikkate alınarak aşağıdaki öneriler verilebilir;

Baba mesleğine ilişkin bulgulardan hareketle, babaların mesleklerinin çocuklarıyla ilişkilerini olumsuz etkilemesine firsat vermeden çocuklarıyla düzenli bir şekilde zaman geçirmelerinin gerekli olduğu düşünülmektedir. Buna yönelik olarak İlçe Milli Eğitim Müdürlükleri ile okul öncesi öğretmenleri iş birliği yaparak okullarda ders saatleri dışındaki uygun vakitlerde baba katılıma yönelik aktiviteler düzenlenmeli ve babalara, çocuklarıyla nitelikli zaman geçirmelerinin önemi vurgulanmalıdır. Ayrıca babalara "MEB Eğitim Takvimi"nin her güne özel hazırlanan aile katılım etkinliklerinden faydalanması ve haftada bir etkinliği çocuğuyla birlikte uygulaması istenebilir.

Çocukların motivasyon düzeyi ile baba-çocuk ilişkisi arasındaki ilişkinin öneminden hareketle, eğitimcilerin özellikle kırsal alanlarda düzenli ev ziyaretleri yoluyla motivasyonun çocuğun hem akademik hem de sosyal hayatında başarılı olmasındaki rolüne vurgu yapılarak ebeveynlerin bu konuda anahtar rol oynadıklarını vurgulayıcı eğitim etkinlikleri planlanabilir.

Bu çalışma 48-72 aylık çocuklardan tek seferde toplanan verilerle yapılmıştır. Baba-çocuk ilişkisi ile motivasyon arasındaki ilişkiye yönelik boylamsal çalışmalar yapılarak ilişkinin sabitliği ya da değişimi incelenebilir.

Araştırma, 2018-2019 eğitim öğretim yılında Diyarbakır ili Silvan ilçesindeki ilkokula bağlı anasınıfları ve bağımsız anaokullarında öğrenim gören 48-72 aylık 331 çocuk ile sınırlıdır. Benzer araştırmaların şehir merkezinde ve kırsalda yaşayan babalar ve anneler dahil edilerek karşılaştırmalı bir çalışma olarak yapılması önerilebilir. 
Bilgilendirme / Acknowledgement:

1- Araştırmacıların katkı oranı eșittir.

2- Bu çalışma Gazi Üniversitesi Eğitim Bilimleri Enstitüsü'nde Doç. Dr. Saide ÖZBEY danışmanlığında Ayşe GÖZÜBÜYÜK tarafından hazırlanan "Okul Öncesi Dönem Çocuklarının Motivasyon Düzeyleri ile Baba-Çocuk İlişkisi ve Bağlanma Biçimleri Arasındaki İlişkinin İncelenmesi” isimli yüksek lisans tezinden üretilmiştir.

3- Makalenin verileri 2019 yılında toplanmıştır.

4- Araştırmada kullanılan ölçekler için gerekli izinler alınmıştır.

5- Makalenin yazarları arasında çıkar çatışması bulunmamaktadır.

6- Bu makalede araştırma ve yayın etiğine uyulmuştur.

\section{KAYNAKÇA}

Akbaba, S. (2006). Eğitimde motivasyon. Atatürk Üniversitesi Kazım Karabekir Eğitim Fakültesi Dergisi, 13, 343-361.

Aksoy, A. B. ve Tatlı, S. (2019). Okul öncesi dönem çocuğu olan babaların çocuklarıyla olan ilişkileri ile babalık rolü algıları arasındaki ilişkinin bazı değişkenler açısından incelenmesi. Çankırı Karatekin Üniversitesi Sosyal Bilimler Enstitüsü Dergisi, 10(1), 1-22.

Aktürk, F. M. (2015). Çocukları okul öncesi eğitime devam eden (5 yaş grubu) ebeveynlerin ana-baba tutumlarının farklı değişkenler açısından incelenmesi. Yayımlanmamış yüksek lisans tezi, Selçuk Üniversitesi Sosyal Bilimler Enstitüsü, Konya.

Arıkan, R. (2011). Araştırma yöntem ve teknikleri. Ankara: Nobel.

Arslan, Ü. ve Durmaz Kandaz, U. (2004). Babaların 3-6 yaş grubundaki çocukların eğitimine ve bakımına katılım durumlarının psikososyal davranışlarına etkisi. I. Uluslararası Okul Öncesi Eğitimi Kongresi Kongre Kitabı, 3, 371-379.

Atmaca Koçak, A. (2004). Baba destek programı değerlendirme raporu. İstanbul: AÇEV.

Bandura, A. (1977). Self-efficacy: Towards a unifying theory of behavioral change. Psychological Review, 84(2), 191-215.

Buckley, C. K. and Schoppe-Sullıvan, S. J. (2010). Father involvement and coparenting behavior: Parents' nontraditional beliefs and family earner status as moderators. Personal Relationships, 17(3), 413-431.

Bulanda, R. E. (2004). Paternal involvement with children: the influence of gender ideologies. Journal of Marriage And Family, 1(66), 40-45.

Castillo, J., Welch, G., ve Sarver, C. (2011). Fathering: The relationship between fathers' residence, fathers' sociodemographic characteristics and father involvement. Maternal and Child Health Journal, 15(8), 1342-1349.

Dede, Y. ve Argün, Z. (2004). Öğrencilerin matematiğe yönelik içsel ve dışsal motivasyonlarının belirlenmesi. Eğitim ve Bilim Dergisi, 29(134), 49-54.

Demir, S. (2018). Okul yöneticilerinin kullandıkları motivasyonel dil ile ögretmen motivasyonunun incelenmesi. Yayımlanmamış doktora tezi, Gaziantep Üniversitesi Eğitim Bilimleri Enstitüsü, Gaziantep.

Ergin, A. ve Karataş, H. (2018). Üniversite öğrencilerinin başarı odaklı motivasyon düzeyleri. Hacettepe Üniversitesi Ĕgitim Fakültesi Dergisi, 33(4), 868-887.

Flouri, E. and Buchanan, A. (2003). The role of father involvement in children's later mental health. Journal of Adolescence, 26, 63-78. 
Gültekin Akduman, G. ve Türkoğlu, D. (2015). Okul öncesi dönem çocuğu olan babaların babalık rolü algısı ile çocuklarının sosyal becerileri arasındaki ilişkinin incelenmesi. Karadeniz Sosyal Bilimler Dergisi, 7(3) , 224-241

Güney, S. (2012). Örgütsel davranış. Ankara: Nobel.

Karasar, N. (2014). Bilimsel araştırma yöntemi: Kavramlar, ilkeler, teknikler. Ankara: Nobel.

Kuruçırak, Ş. (2010). 4-12 aylık bebeği olan babaların, babalık rolü algısı ile bebek bakımına katılımı arasındaki ilişki. Yayımlanmamış yüksek lisans tezi, Akdeniz Üniversitesi Sağlık Bilimleri Enstitüsü, Antalya.

Mwoma, B. T. (2009). Paternal involvement in children's education: An implication of children's performance at preschool in Gucha district Kenya. Yayımlanmamış yüksek lisans tezi, Kenyatta University, Kenya.

Nkwake, A. (2009). Maternal employment and fatherhood: What influences paternal involvement in child-care work in Uganda? Gender \& Development, 17(2), 255-267.

Özbey, S. ve Dağlıoğlu, H. E. (2017). Adaptation study of the motivation scale for the preschool children (DMQ18). International Journal of Academic Research, 4, 2(1), 1-14.

Özbey, S. (2018a). Okul öncesi dönem çocuklarında motivasyon ve öz düzenleme becerileri üzerine bir inceleme. Akademik Sosyal Araştırmalar Dergisi, 6(65), 26-47.

Özbey, S. (2018b). Okul öncesi dönem çocuklarının ahlaki değer davranışları ile motivasyon düzeyleri arasındaki ilişkinin incelenmesi. Uluslararası Eğitim Bilimleri Dergisi, 5(16), 1-15.

Özkan, T. (2014). Çocuğu okul öncesi eğitim kurumuna devam eden babalara uygulanan baba katılım programının baba-çocuk ilişkisi üzerine etkisi. Yayımlanmamış yüksek lisans tezi, Gazi Üniversitesi Eğitim Bilimleri Enstitüsü, Ankara.

Özmert, E., Yurdakök K. ve Soysal A.Ș. (2001). Ankara'da ilkokul birinci sınıf öğrencilerinde okul başarısızlığına yol açan faktörler. Çocuk Sağlığı ve Hastalıkları Dergisi, 44, 4-18.

Özsoy Yanbak, M. (2019). Okul öncesi eğitime devam eden çocukların öz düzenleme becerileri ile baba çocuk ilişkisinin incelenmesi. Yayımlanmamış yüksek lisans tezi, Gazi Üniversitesi Eğitim Bilimleri Enstitüsü, Ankara.

Poyraz, M. (2007). Babaların babalık rolünü algılamalarıla kendi ebeveynlerinin tutumları arasındaki ilişkinin incelenmesi. Yayımlanmamış yüksek lisans tezi, Gazi Üniversitesi Eğitim Bilimleri Enstitüsü, Ankara.

Şahin, H. ve Demiriz, S. (2014). Beş altı yaşında çocuğu olan babaların, babalık rolünü algılamaları ile aile katılım çalışmalarını gerçekleştirmeleri arasındaki ilişkinin incelenmesi. Türkiye Sosyal Araştırmalar Dergisi, 18(1), 273-294.

Telli, A. A. (2014). 3-6 yaş grubu çocuğu olan babaların babalık rolü algısı ve etkileyen faktörlerin belirlenmesi. Yayımlanmamış yüksek lisans tezi, Atatürk Üniversitesi Sağlık Bilimleri Enstitüsü, Erzurum.

Tezci, E., Sezer, F., Gürgan, U. ve Aktan, S. (2015). A study on social support and motivation. Anthropologist, 22(2), 284-292.

Tezel Şahin, F., Akıncı Coşgun, A. ve Kılıç Aydın, Z. N. (2017). Babaların çocuklarıyla vakit geçirme durumlarına ilişkin görüşlerinin incelenmesi. GEFAD/GUJGEF, 37(1), 319-343.

Topçu, S. (2015). Üstün ve normal zihin düzeyine sahip ögrencilerde içsel-dlşsal motivasyon ve benlik saygı düzeyi arasındaki ilişki. Yayımlanmamış yüksek lisans tezi, İstanbul Üniversitesi Eğitim Bilimleri Enstitüsü, İstanbul.

Uzun, H. ve Baran, G. (2015). Çocuk ebeveyn ilişki ölçeği'nin okul öncesi dönemde çocuğu olan babalar için geçerlik ve güvenirlik çalışması. Uluslararası Eğitim Bilimleri Dergisi, 2(3), 30-40. 
Uzun, H. ve Baran, G. (2019). Babaların okul öncesi dönemdeki çocuklarıyla ilişkisinin bazı değişkenlere göre incelenmesi. Mersin University Journal of the Faculty of Education, 15(1), 47-60.

Ünüvar, P. (2008). Babaların 3-6 yaş grubu çocuklarıyla geçirdikleri zamanın niteliğini belirleme ve geliştirme. Yayımlanmamış doktora tezi, Selçuk Üniversitesi Sosyal Bilimler Enstitüsü, Konya.

Yavuzer, H. (2012). Anne-baba ve çocuk. (23. baskı). İstanbul: Remzi Kitapevi.

Yücel Batmaz, N. ve Gürer, A. (2016). Dönüştürücü liderliğin çalışanların içsel motivasyonu üzerindeki etkisi: Yerel yönetimlerde karşılaştırmalı bir araştırma. Süleyman Demirel Üniversitesi İktisadi ve İdari Bilimler Fakültesi Dergisi, 21(2), 477-492. 